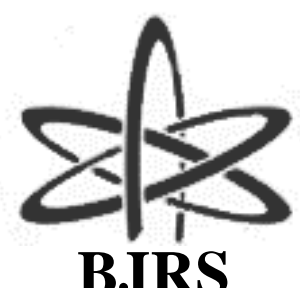

BJRS
BRAZILIAN JOURNAL

$\mathrm{OF}$

RADIATION SCIENCES

09-01A (2021) 01-18

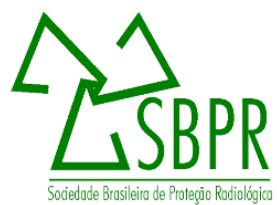

\title{
Use of ionizing radiation for the inhibition and removal of cyanotoxins in water: A brief review
}

\author{
Silva ${ }^{\mathrm{a}}$ T.T., Borrely ${ }^{\mathrm{a}}$ S.I. \\ ${ }^{a}$ Instituto de Pesquisas Energéticas e Nucleares/Centro de Tecnologia das Radiações 05508-000,São Paulo, SP, \\ Brazil \\ thalita.tieko.silva@usp.br
}

\begin{abstract}
Cyanobacteria are an ancient and diverse group of microorganisms, considered as important contributors to the formation of Earth's atmosphere and nitrogen fixation. However, the input of nutrients in water by anthropogenic activities frequently provides cyanobacteria blooms associated with toxic compounds. Secondary metabolites, also called cyanotoxins, are often harmful to wild and domestic life, including humans. The first part of this review focuses on cyanobacteria and their ability to produce a variety of toxins as well as describe the Brazilian guidelines on the evaluation and management of these toxins in water quality. Then, we present a review of recent literature on the use of ionizing radiation in terms of cyanobacteria cell removal, degree of degradation of cyanotoxins in water, and reaction kinetics. In view of the exposed results, the paper concludes that ionizing radiation is an efficient and economically viable alternative for the remediation of areas contaminated by cyanobacterial blooms and cyanotoxins, especially in reservoirs intended for water treatment and supply. In addition, some suggestions are provided for further studies on the use of this technology in the treatment of drinking water.
\end{abstract}

Keywords: cyanobacteria, cyanotoxins, ionizing radiation, irradiators.

ISSN: 2319-0612

Accepted: 2021-01-03 


\section{INTRODUCTION}

Cyanobacteria, also known as blue algae or cyanophytes, are gram-negative bacteria [1] and they are present in aquatic and terrestrial ecosystems, such as lakes [2,3], ponds [4], hot springs [5,6], oceans [7,8], tropical forests [9], symbioses [10], and surface soils [11]. The first record of these organisms dates from about 3.5 billion years ago, and they are probably the first primary producers of organic matter to release elemental oxygen into the primitive atmosphere [12].

These microorganisms can convert the solar radiation into organic matter and oxygen due the presence of chlorophyll-a, yellowish carotenoids, phycobilin, and, in some species, phycoerythrin in their cells [1,13]. Furthermore, they do not have membrane-associated photosynthesis organelles, as the photosynthetic pigments are in the free thylakoids in the cytoplasm. Many species are also able to fix atmospheric nitrogen $\left(\mathrm{N}_{2}\right)$ toward compounds that can be employed by living cells. Afterward, these compounds can be assimilated into amino acids and proteins [14,15].

In contrast to eukaryotic microalgae, cyanobacteria do not have defined nuclei, thus resembling bacteria. They occur in different forms, as simple unicells, colony-forming, and undifferentiated filamentous, also known as trichomes. The cells are found in different shapes, e.g., spheres, rods, oval, fusiform, irregular or cylindrical forms. The microalgae and cyanobacteria have the ability to synthesize extracellular polysaccharides (EPSs), which can be excreted by sheaths, capsules or release as mucilage. EPSs are able to be incorporated to the cell-wall and form colonies by the cluster of single cells [16,17]. Some of the filamentous forms evolved to have specialized cells heterocysts - for nitrogen fixation and akinetes as resting stages [14,15].

Eutrophication initiates from nutrients supply, mainly nitrogen $(\mathrm{N})$ and phosphorus $(\mathrm{P})$ which influences the formation of cyanobacterial harmful algal blooms. The input of these nutrients into surface waters is related by sewage disposal, industrial activities, and extensive agricultural practices [1]. Studies have suggested that blooms and dominant groups are also caused by a complex interaction of high concentrations of nutrients and physical-chemical parameters, such as sunlight, nutrient levels, water temperature, turbidity, $\mathrm{pH}$ levels, conductivity, dissolved oxygen and water flow $[1,18]$. 
The climatic conditions of a region play an important role in the time and duration of the flowering of cyanobacteria. In the temperate zone, cyanobacteria blooms is usually pronounced during late summer or later autumn, and rarely reported in winter. On the other hand, in more Mediterranean and subtropical regions, blooms may persist for longer [19]. The significant presence of cyanobacteria blooms in marine and freshwater environments is an issue to be solved. The reason is because previous investigations have shown that these blooms may be toxic. In fact, it is estimated that between 25 and $35 \%$ of the Spanish reservoirs are highly likely to develop toxic cyanobacterial blooms [20]. In Brazil, some common freshwater genera are Cylindrospermopsis, Microcystis, Planktothrix, Aphanizomenon, Dolichospermum (ex Anabaena), and Raphidiopsis [21-24].

In this review, we present the recent studies of the literature on the use of ionizing radiation to treat cyanobacteria and microcystins (MCs) in water. The most remarkable data of the literature are present and discussed regarding the degree of removal of these toxic compounds and reaction kinetics by electron beam and gamma-ray irradiations. Furthermore, Brazilian guidelines on this subject are briefly provided to assist investigators dealing with this challenge.

\section{CYANOTOXINS}

Cyanotoxins are toxic secondary metabolites and responsible for acute and chronic poisoning of wild/domestic animals and humans. According to toxicological target, it can be divided in four classes: hepatotoxins (MCs and Nodularin), cytotoxins (Cylindrospermopsin), neurotoxins (Anatoxins, Saxitoxins, and BMAA), and dermatotoxins (Lipopolysaccharide, Lyngbyatoxins, and Aplysiatoxin) [25].

The cyanobacterial toxins naturally occur intracellularly (in the cytoplasm) and are retained within the cell. About $95 \%$ of the time during the growth stage of the bloom, some varieties of cyanotoxin, including anatoxin-a and the microcystin variants, are intracellular [26]. In such circumstances and for such species, the toxins are discharged into the water during cellular senescence, death, and lysis, rather than continuous excretion (extracellular toxins). Nevertheless, in other species, e.g., cylindrospermopsin, a serious amount of the toxin may be normally freed to the water by 
the live cyanobacterial cell. According to EPA [26], the reported ratio is about half intracellular, half extracellular.

\subsection{Hepatotoxins}

Hepatotoxin is the most common and worldwide documented intoxication and comprises MCs (heptapeptides), nodularins NODs (pentapeptides), and cylindrospermopsin CYN (an alkaloid). MCs and NODs are both cyclic peptides and therefore, have similar toxicity mechanisms [25].

MCs are cyclic heptapeptides with the general formula cyclo-(D-Ala ${ }^{1} X^{2}-D-M e A s p^{3}-Z^{4}-A_{d d a} 5$ D-Glutamate $\left.{ }^{6}-\mathrm{Mdha}^{7}\right)$. Adda refers to $(2 \mathrm{~S}, 3 \mathrm{~S}, 8 \mathrm{~S}, 9 \mathrm{~S})-3$-amino-9-methoxy-2,6,8-trimethyl-10phenyldeca-4,6-dienoic acid, unique for cyanobacteria [27]. According to the literature [19,28], MCs are produced by the following genera: Dolichospermum, Anabaenopsis, Aphanizomenon, Microcystis, Nostoc, and Oscillatoria (ex Planktothrix). The positions 2 (X) and 4 (Z) result in structural variations of the microcystin molecule. These two qualitative variations observed in their Lamino acids are used to designate the different MCs [19].

Currently, about 100 variants have been identified. As previously stated, MC-LR is the most common and most studied congener, followed by MC-RR (with two arginines at positions 2 and 4) and MC-YR [28]. For the time being, MC-LR is considered as the reference compound among MCs due to its toxicity and high occurrence.

NODs are only produced by Nodularia genera and some studies pointed their production by the Nostoc genera [29,30]. NODs are monocyclic pentapeptide hepatotoxin and their general formula is cyclo-(D-MeAsp ${ }^{1}$-L-arginine ${ }^{2}-$ Adda $^{3}$-D-Glutamate ${ }^{4}-\mathrm{Mdhb}^{5}$ ). Nowadays, eight variants are known [28] and classified according to variations in the number of methyl groups in their amino acids [31].

Globally, the cyanotoxins most frequently found in cyanobacteria flowering freshwater are the cyclic peptide toxins of the MC and NOD families [19]. The most serious known episode associated with human MC exposure in the world occurred in Caruaru, Brazil, wherein 54 of the 130 hemodialysis patients died after treatment with water accidentally contaminated with MC [32].

Liver damage and insufficiency in liver functions are common consequences of poisoning by MCs and NODs. Similar effects have been seen within the gastrointestinal tract and kidneys alt- 
hough less severe. Kidney effects are observed through lesions and cell damage in both the glomeruli and collection tubules, with attendant increases in blood urea N, creatinine, and potassium [33].

\subsection{Cytotoxins}

Cylindrospermopsin (CYN) consists of a tricyclic guanidine group combined with a hydroxylmethyl uracil group [34]. It is biosynthesized by genera Cylindrospermopsis, Aphanizomenon, Umezakia, Raphidiopsis, Dolichospermum, and Lyngbya [19,28].

The intoxication by cytotoxins affect mainly the liver, but many other organs can be affect such as kidneys, lungs, thymus, marrow bone, adrenal gland, gastrointestinal tract, immune and nervous systems, and heart [35].

\subsection{Neurotoxins}

The most studied cyanobacterial neurotoxins are alkaloids compounds, namely anatoxins and saxitoxins. The neurotoxins are produced by marine dinoflagellates, [36] and species of freshwater cyanobacteria [37].

Anatoxins are water-soluble neurotoxins made by the Dolichospermum, Plantkothrix, Oscillatoria, Microcystis, Aphanizomenon, Cylindrospermum and Phormidium genera [38]. There exist three categories of anatoxin, namely anatoxin-a, homoanatoxin-a (structural homologue to anatoxin-a), and anatoxin-a(s) [39].

Anatoxin-a (ATX-a) is a potent post-synaptic neuromuscular blocker of nicotinic and cholinergic receptors. This blocking occurs because the anatoxin-a binds irreversibly to acetylcholine receptors, as it is not degraded by acetylcholinesterase [37]. Clinical signs of intoxication show a progression of muscle fasciculation, decreased movement, exaggerated abdominal breathing, cyanosis, and convulsion. ATX-a is a secondary amine bicyclic alkaloid [37] and produced by Dolichospermum, Cylindrospermum, Aphanizomenon, and Oscillatoria species [40].

Anatoxin-a(s) (ATX-a(s)) shows the same toxicity behaviour of that of the ATX-a, added to the salivation(s) [41]. This neurotoxin has a mechanism of action similar to ATX-a, as it inhibits the action of acetylcholinesterase, preventing the degradation of acetylcholine-gated receptors [42]. 
Saxitoxins (STX) have demonstrated to be harmful to shellfish, causing the so-called paralytic shellfish poisoning (PSP) [36,43]. STX belongs to a family of a series of carbamate alkaloid neurotoxins and are known to accumulate in filter-feeding organisms, e.g. mussels and clams [44]. STX are produced by some genera of marine dinoflagellates (Alexandrium, Pyrodinium and Gymnodinium) $[21,43]$ and freshwater cyanobacteria genera. In the latter are included Dolichospermum, Cylindrospermopsis, Planktothrix, Lyngbya and Aphanizomenon [19,21,38]. These toxins are usually grouped into carbamate (STX, neoSTX and GTX1-4), sulfamate (GTX 5-6, C1-4) and decarbamol (dcSTX dcneoSTX, dcGTX1-4) based on the substituent at position R4 [45].

$\beta-\mathrm{N}$-methylamino-L-alanine (BMAA) is a nonprotein amino acid [46] and has been associated with neurodegenerative disease [46,25]. As BMAA is not lipophilic, it would not be expected to biomagnify, yet the indirect evidence suggests that it can biomagnify at least in certain circumstances [47].

\subsection{Dermatotoxins}

Some cyanotoxins are known to affect the skin, namely dermatotoxins. This group includes Aplysiatoxin (APX), Lyngbyatoxin (LT) and Lypopolysaccharide (LPS) [25]. APX has phenolic bislactones and it is synthesized by Lyngbya majuscula freshwater species [25]. They are persistent skin irritants, provoking skin rashes and blistering. LT is an indole alkaloid generated by benthic cyanobacteria L. majuscule [48,49,25] and it is known three isoforms: A (LTA) [48], B (LTB), and C (LTC) [49]. LTA compound can trigger dermatitis and inflammation of oral and gastrointestinal tissues [19]. LPS is present in the outer membrane layer of cyanobacteria cells [25]. Concern is that dermatotoxins are the least examined toxins among cyanotoxins.

\section{GUIDANCE VALUES FOR CYANOTOXINS}

World Health Organization (WHO) [50] sets a guideline of $1 \mu \mathrm{g} \mathrm{L}^{-1}$ for maximal acceptable of MC-LR concentrations in drinking water. This guideline has been adopted by several countries to assess and manage the risk associated with recreational activities. In Australia, guidelines for drink- 
ing water quality set a critical limit of 6500 cell $\mathrm{mL}^{-1}$ with a target value of 1000 cell $\mathrm{mL}^{-1}$. The monitoring occurs with the determination of temperature and dissolved oxygen through the water column. Furthermore, regular sampling is required when cyanobacterial cell increases are detected or in the period of greatest frequency (summer) [51].

Specifically, in Brazil, the guidance values for cyanotoxins are determined by Health Ministry (Regulation 2914/2011) [52], which provides the procedures and responsibilities related to the control and monitoring quality of water for human consumption and potability standards. The regulation determines the monthly monitoring at the point of water captation when the number of cyanobacteria cells does not exceed 10.000 cells $\mathrm{mL}^{-1}$. When a value of more than 20.000 cells $\mathrm{mL}^{-1}$ of cyanobacteria occurs, the weekly analysis of cyanotoxins must be performed, mainly for analyzing MCs and STX due to their acute and carcinogenic effects [23].

For CYN, Regulation 2914/2011 recommends this analysis whenever the presence of genera potentially toxin-producing is detected, with the maximum acceptable value of $1.0 \mu \mathrm{g} \mathrm{L}^{-1}$. For the presence of ATX-a(s), it should be analyzed when the presence of cyanobacteria genera with the potential of producing this cyanotoxin is spotted during the monitoring of the water body. It is worth mentioning that there is no determination of an acceptable maximum limit (AML) regarding ATX-a.

In Brazil, the most used technology in water treatment is the conventional one, composed of coagulation, flocculation, decantation or flotation, filtration, disinfection, $\mathrm{pH}$ correction, and fluoridation. The conventional treatment to be used is classified by Regulation 357/2005 - CONAMA [53] and applied in varieties of water categories. In natural waters with high algal concentration, the use of flotation followed by rapid filtration guarantees removal efficiency of cyanobacterial cells. However, high concentration of cyanotoxins generally is not efficiently removed by conventional treatment processes, such as coagulation-flocculation, sedimentation and filtration [54]. 


\section{IONIZING RADIATION FOR THE REMOVAL OF CYANOBACTERIA IN WATER}

Advanced Oxidation Processes (AOP) are characterized by the formation of reactive and shortlived oxygen-containing molecules such as hydroxyl radicals $(\bullet \mathrm{OH})$ and they are known for utilizing the high reactivity of these species to degrade persistent organic compounds [55] and their complete mineralization to carbon dioxide, water and inorganics.

The hydroxyl radical is very attractive since it is a powerful oxidant, short-lived, highly reactive, unselective, besides being of easy production by a plethora of processes [55]. Furthermore, hydroxyl radical is known for your largely presence in nature, and in many processes that occur in the human body, including the aging process [56].

Ionizing radiation generates highly reactive products (electrons, free radicals, ions, and excited species) in any system. Among the existing AOP, this review highlights ionizing radiation, which is an efficient method of generating radicals and, therefore, provide oxidation, modification, and finally degradation of organic molecules [57].

The $\cdot \mathrm{OH}$ radical, by virtue of its high yield as well of its high oxidation potential is the predominant oxidative species, but reducing species such as the hydrated electron $\left(\mathrm{e}_{\mathrm{aq}}-\right)$ are also formed.

The absorbed energy by the solution is due to irradiation, which generates instability with atoms and molecules, producing free radicals in cells. The radicals can act directly critical parts on the plant cells, depending of the amount of water presented [58] and damage or modify important components of them depending on the dose.

In water and other aqueous solutions, high energy irradiation produces instantaneous transformations by energy transfer from photons or accelerated electrons to the orbital electrons of water molecules. This transference results in the breakage of interatomic bonds and the production of highly reactive products. This process is known as water radiolysis and is described by Equation (1):

$$
\mathrm{H}_{2} \mathrm{O} \rightarrow \cdot \mathrm{OH}(0.28)+\cdot \mathrm{H}(0.06)+\mathrm{e}_{\mathrm{aq}}-(0.27)+\mathrm{H}_{2}(0.05)+\mathrm{H}_{2} \mathrm{O}_{2}(0.07)+\mathrm{H}_{3} \mathrm{O}^{+}(0.27)
$$


where the numbers in brackets are yields (G-values) per $100 \mathrm{eV}$ absorbed energy [59]. The predominant oxidative species in this system is the $\bullet \mathrm{OH}$. However, reducing species such as the hydrated electron $\left(\mathrm{e}_{\mathrm{eq}}^{-}\right)$are also formed. The products of water radiolysis are highly reactive, promoting a fast reaction with the organic compounds dissolved in water. This interaction may lead to organics degradation and as a result, many applications of radiation treatment of waste in polluted water and wastewater have been described in the literature [60-62]. Two types of irradiators were applied during the studies: electron beam accelerators and cobalt gamma sources $\left({ }^{60} \mathrm{Co}\right)$.

\subsection{Gamma-ray radiation}

Duarte et al. [63] have tested the efficiency of gamma-ray radiation in odoriferous compounds geosmin (GEO) and methylisoborneol (MIB) in three types of water: demineralized water (concentrations of GEO and MIB were known), raw water (before the conventional treatment), and after conventional treatment. The samples were tested with $0.5,1.0,1.5,2.0$, and $3.0 \mathrm{kGy}$. The concentration of GEO and MIB decreased $90 \%$ by using $1 \mathrm{kGy}$ for all types of water.

Zhang et al. [64] studied the degradation of two congeners MCs in water: MC-LR and MC-RR. They observed that MC-LR decreased $98.8 \%$ by using $8 \mathrm{kGy}$, while $100 \%$ of MC-RR was degraded at $5 \mathrm{kGy}$. In the same study, the authors used $\mathrm{Na}_{2} \mathrm{CO}_{3}, \mathrm{H}_{2} \mathrm{O}_{2}$, Triton $\mathrm{X}-100, \mathrm{NaNO}_{3}$, and $\mathrm{NaNO}_{2}$ to evaluate the efficiency of degradation. As a result, the degradation in the presence of $\mathrm{Na}_{2} \mathrm{CO}_{3}$ at 1.0 and $5 \mathrm{kGy}$ for MCs was a little higher when compared with the absence of this chemical compound. However, at the same doses, the degradation of MCs decreased when it used Triton-X, $\mathrm{NaNO}_{3}$, and $\mathrm{NaNO}_{2}$. Among all of these additives, $\mathrm{H}_{2} \mathrm{O}_{2}$ presented the best result.

Song et al. [65] determined the kinetic parameters and the primary first reaction pathways for the reaction of the $\bullet \mathrm{OH}$ radical with MC-LR. The study demonstrated that the reaction of hydroxyl radical with MC-LR can occur via a number of competing reaction pathways, including addition to the benzene ring and diene and abstraction of aliphatic hydrogen atoms. LC-MS analyses indicate the major products from the reaction of hydroxyl radicals with MC-LR involve the addition of $\bullet \mathrm{OH}$ radical to the benzene ring and diene moieties of the Adda side chain. 
Cavalcante et al. [66] have studied the cyanobacteria Microcystis panniformis exposed to $4 \mathrm{kGy}$, $5 \mathrm{kGy}$, and $6 \mathrm{kGy}$, with an equivalent dose rate of $0.591 \mathrm{kGy} \mathrm{h}^{-1}$. After $48 \mathrm{~h}$, it was observed a mortality of 20.3 and $99.9 \%$ with 4 and $6 \mathrm{kGy}$, respectively. After 5 days, it was observed $76.4 \%$ and $100 \%$ at the same doses. The results showed that $M$. panniformis is radioresistant when compared with other species.

Zheng et al. [67] have studied the effects of gamma-ray radiation on the morphology, photosynthetic pigments, enzyme activities, $\mathrm{pH}$, and the presence of additives on $M$. aeruginosa. The concentration of photosynthetic pigments decreased in response to increased doses. The activity of superoxide dismutase and peroxidase enhanced with doses between 2 and $5 \mathrm{kGy}$ but decreased at higher doses (6-9 kGy). After 5 days, it was observed the removal efficiency of $M$. aeruginosa was $98 \%$ when treated with $9 \mathrm{kGy}$.

\subsection{Electron beam irradiation (EBI)}

Liu et al. [68] have used electron beam irradiation to investigate the inactivation of $M$. aeruginosa. After 11 days, they obtained removal efficiency of 91 and $84 \%$ to 4.0 and $5.0 \mathrm{kGy}$, respectively, when compared to control. The photosynthesis rate decreased significantly with doses between 2 and $5 \mathrm{kGy}$. In the study, the damages caused by EBI in the cyanobacteria and further observed in antioxidant enzymes demonstrated that cells cannot survive after radiation exposure.

Liu et al. [59] studied the effects of electron beam on M. aeruginosa control and MC-LR degradation. There was a fluctuation in the intercellular MC - LR concentration under the doses between 2 and $5 \mathrm{kGy}$, indicating that an appropriate dose of EBI is able to inhibit the intercellular MC production. The removal of total MC concentration (intercellular + extracellular) was $72.1 \%$ when 5 kGy was employed.

\section{CONCLUSIONS}

The potential risk from exposure to cyanotoxins for both human and animal health are assuming a relevance due to greater demands on water resources for drinking, recreation, aquaculture and 
irrigation, and for the discharge of wastewater due to population growth. To avoid aquatic contamination it is crucial to control the blooms of cyanobacteria.

For risk management procedures to be effective, advances in knowledge are critical to the adoption of appropriate regulations or guidelines for the protection of human and animal health. Allied to this idea, new technologies to the treatment of drinking water need to be developed or further studied for the removal of cyanobacteria cells or their toxins.

Advanced oxidation processes, specifically ionizing radiation, appear to be a promising technology for the destruction of cyanobacteria cells and their cyanotoxins in drinking water. Additional research is necessary for the determination and toxicity of products generated by the degradation of these cyanotoxins in water. Also, studies with other cyanotoxins are necessary, since gamma radiation and electron beam proved to be efficient for the removal of MC.

\section{ACKNOWLEDGMENT}

The authors thank CNEN (Comissão Nacional de Energia Nuclear) for the fellowship awarded to T.T. Silva and IAEA (International Atomic Energy Agency - RC 23033) for financial support.

\section{REFERENCES}

[1] DUY, T. N.; LAM, P. K.; SHAW, G. R.; CONNELL, D. W. Toxicology and risk assessment of freshwater cyanobacterial (blue-green algal) toxins in water. In: Reviews of environmental contamination and toxicology, Springer, New York, NY, 2000. p. 113-185.

[2] SALMASO, N.; CERASINO, L.; BOSCAINI, A.; CAPELLI, C. Planktic Tychonema (Cyanobacteria) in the large lakes south of the Alps: phylogenetic assessment and toxigenic potential. FEMS Microbiol Ecol, v. 92(10), p. fiw155, 2016.

[3] DOWNING, J.A.; WATSON, S.B.; MCCAULEY, E. Predicting cyanobacteria dominance in lakes. Can J Fish Aquat Sci, v. 58(10), p.1905-1908, 2001. 
[4] SEVRIN-REYSSAC, J.; PLETIKOSIC, M. Cyanobacteria in fish ponds. Aquac, v. 88(1), p.1$20,1990$.

[5] PAPKE, R. T.; RAMSING, N. B.; BATESON, M. M.; WARD, D.M. Geographical isolation in hot spring cyanobacteria. Environ Microbiol, v. 5(8), p.650-659, 2003.

[6] STRUNECKÝ, O.; KOPEJTKA, K.; GOECKE, F.; TOMASCH, J.; LUKAVSKÝ, J.; NEORI, A.; KAHL, S.; PIEPER, D. H.; PILARSKI, P.; KAFTAN, D.; KOBLÍŽEK, M. High diversity of thermophilic cyanobacteria in Rupite hot spring identified by microscopy, cultivation, single-cell PCR and amplicon sequencing. Extremophiles, v. 23(1), p.35-48, 2009.

[7] HOFFMAN, L. Marine cyanobacteria in tropical regions: diversity and ecology. Eur J Phycol, v. 34(4), p.371-379, 1999.

[8] XIA, X.; PARTENSKY, F.; GARCZAREK, L.; SUZUKI, K.; GUO, C.; YAN CHEUNG, S.; LIU, H. Phylogeography and pigment type diversity of Synechococcus cyanobacteria in surface waters of the northwestern pacific ocean. Environ Microbiol, v. 19(1), p.142-158, 2017.

[9] HENTSCHKE, G. S.; JOHANSEN, J. R.; PIETRASIAK, N.; FIORE, M. D. F.; RIGONATO, J.; SANT'ANNA, C. L.; KOMAREK, J. Phylogenetic placement of Dapisostemon gen. nov. and Streptostemon, two tropical heterocytous genera (Cyanobacteria). Phytotaxa, v. 245(2), p.129-143, 2016.

[10] RAI, A. N. Cyanobacteria in symbiosis. In: RAI, A. N. CRC handbook of symbiotic cyanobacteria, CRC Press, 2018. p. 1-7.

[11] BÜDEL, B.; DULIĆ, T.; DARIENKO, T.; RYBALKA, N.; FRIEDL, T. Cyanobacteria and algae of biological soil crusts. In: WEBER, B.; BÜDEL, B.; BELNAP, J. Biological soil crusts: an organizing principle in drylands, Springer, Cham, 2016. p. 55-80.

[12] SCHOPF, J. W. The fossil record: tracing the roots of the cyanobacterial lineage. In: WHITTON, B. A.; POTTS, M. The ecology of cyanobacteria, Springer, Dordrecht, 2000. p. 13-35.

[13] SAINI, D. K.; PABBI, S.; SHUKLA, P. Cyanobacterial pigments: perspectives and biotechnological approaches. Food Chem Toxicol, v. 120, p.616-624, 2018.

[14] FAY, P. Oxygen relations of nitrogen fixation in cyanobacteria. Microbiol Mol Biol R., v. 56(2), p.340-373, 1992. 
[15] BERMAN-FRANK, I.; LUNDGREN, P.; FALKOWSKI, P. Nitrogen fixation and photosynthetic oxygen evolution in cyanobacteria. Res Microbiol, v. 154(3), p.157-164, 2003.

[16] MAGER, D. M.; THOMAS, A. D. Extracellular polysaccharides from cyanobacterial soil crusts: a review of their role in dryland soil processes. J Arid Environ, p. 75(2), p.91-97, 2011.

[17] ROSSI, F.; DE PHILIPPIS, R. Exocellular polysaccharides in microalgae and cyanobacteria: chemical features, role and enzymes and genes involved in their biosynthesis. In: BOROWITZKA, M. A.; BEARDALL, J.; RAVEN, J. A. The physiology of microalgae, Springer, Cham, 2016. p. 565-590.

[18] GOLSHAN, A.; EVANS, C.; GEARY, P.; MORROW, A.; MAEDER, M.; TAULER, R. Patterns of cyanobacterial abundance in a major drinking water reservoir: what 3 years of comprehensive monitoring data reveals?. Environ Monit Assess, v. 192(2), p.1-11, 2020.

[19] SIVONEN K.; JONES G. Cyanobacterial toxins. In: CHORUS I.; BARTRAM J. Toxic Cyanobacteria in Water. A Guide to their Public Health Consequences, Monitoring and Management. London: E \& FN Spon, WHO; 1999. p. 41-112.

[20] QUESADA, A.; SANCHIS, D.; CARRASCO, D. Cyanobacteria in Spanish reservoirs. How frequently are they toxic?. Limnetica, v. 23(1-2), p. 109-118, 2004.

[21] LAGOS, N.; ONODERA, H.; ZAGATTO, P. A.; ANDRINOLO, D.; AZEVEDO, S. M.; OSHIMA, Y. The first evidence of paralytic shellfish toxins in the freshwater cyanobacterium Cylindrospermopsis raciborskii, isolated from Brazil. Toxicon, v. 37(10), p.1359-1373, 1999.

[22] FERRÃO-FILHO, A. S.; DOMINGOS, P.; AZEVEDO, S.M. Influences of a Microcystis aeruginosa Kützing bloom on zooplankton populations in Jacarepaguá Lagoon (Rio de Janeiro, Brazil). Limnologica, v. 32(4), p.295-308, 2002.

[23] Carvalho, M. D. C.; AGUjaro, L. F.; PIRES, D. A.; PICOLI, C. Manual de cianobactérias planctônicas: legislação, orientações para o monitoramento e aspectos ambientais. Governo do Estado Sao Paulo. Secretaria do Meio Ambiente, CETESB, 2013. p. 47.

[24] BARROS, M. U.; WILSON, A. E.; LEITÃO, J. I.; PEREIRA, S. P.; BULEY, R. P.; FERNANDEZ-FIGUEROA, E. G.; CAPELO-NETO, J. Environmental factors associated with toxic cyanobacterial blooms across 20 drinking water reservoirs in a semi-arid region of Brazil. Harmful algae, v. 86, p.128-137, 2019. 
[25] SANSEVERINO, I.; ANTÓNIO, D. C.; LOOS, R.; LETTIERI, T. Cyanotoxins: methods and approaches for their analysis and detection. Centre, JR, Ed , 2017.

[26] EPA, U., 2014. Cyanobacteria and Cyanotoxins: Information for Drinking Water Systems

[27] CHORUS, I.; BARTRAM, J. Toxic Cyanobacteria in Water: A guide to their public health consequences , monitoring and management. WHO ed. London: Spon Press, 1999.

[28] BURATTI, F. M.; MANGANELLI, M.; VICHI, S.; STEFANELLI, M.; SCARDALA, S.; TESTAI, E.; FUNARI, E. Cyanotoxins: producing organisms, occurrence, toxicity, mechanism of action and human health toxicological risk evaluation. Arch Toxicol, v. 91(3), p.1049-1130, 2017.

[29] SOTTON, B.; DOMAIZON, I.; ANNEVILlE, O.; CATTANÉO, F.; GUILLARD, J. Nodularin and cylindrospermopsin: a review of their effects on fish. Rev Fish Biol Fisher., v. 25(1), p. 1-19, 2014.

[30] JOKELA, J.; HEINILÄ, L. M.; SHISHIDO, T. K.; WAHLSTEN, M.; FEWER, D. P.; FIORE, M. F.; WANG, H.; HAAPANIEMI, E.; PERMI, P.; SIVONEN, K. Production of high amounts of hepatotoxin nodularin and new protease inhibitors pseudospumigins by the Brazilian benthic Nostoc sp. CENA543. Front Microbiol, v. 8, p.1963, 2017.

[31] RINEHART, K.L.; NAMIKOSHI, M.; CHOI, B.W. Structure and biosynthesis of toxins from blue-green algae (cyanobacteria). J Appl Phycol, v. 6(2), p.159-176, 1994.

[32] JOCHIMSEN, E. M.; CARMICHAEL, W. W.; AN, J.; CARDO, D. M.; COOKSON, S. T.; HOLMES, C. E.; ANTUNES, M. B.; DE MELO FILHO, D. A.; LYRA, T. M.; BARRETO, V. S. T.; AZEVEDO, S. M. Liver failure and death after exposure to microcystins at a hemodialysis center in Brazil. N Engl J Med, v. 338(13), p.873-878, 1998.

[33] BEASLEY, V. R.; LOVELL, R. A.; HOLMES, K. R.; WALCOTT, H. E.; SCHAEFFER, D. J.; HOFFMANN, W. E.; CARMICHAEL, W. W. Microcystin-LR decreases hepatic and renal perfusion, and causes circulatory shock, severe hypoglycemia, and terminal hyperkalemia in intravascularly dosed swine. J Toxicol Env Heal A, v. 61(4), p.281-303, 2000.

[34] OHTANI, I., MOORE, R.E. AND RUNNEGAR, M.T. Cylindrospermopsin: a potent hepatotoxin from the blue-green alga Cylindrospermopsis raciborskii. J Am Chem Soc, v. 114(20), p.7941-7942, 1992. 
[35] SIVONEN, K. Cyanobacterial Toxins. Encyclopedia of Microbiology. (Moselio Schaechter, Editor), p. 290-[307] Oxford: Elsevier.2009

[36] ORR, R. J.; STÜKEN, A.; MURRAY, S. A.; JAKOBSEN, K. S. Evolution and distribution of saxitoxin biosynthesis in dinoflagellates. Mar drugs, v. 11(8), p.2814-2828, 2013.

[37] DEVlin, J. P.; EDWARDS, O. E.; GORHAM, P. R.; HUNTER, N. R.; PIKE, R. K.; STAVRIC, B. Anatoxin-a, a toxic alkaloid from Anabaena flos-aquae NRC-44h. Can J Chem, v. 55(8), p.1367-1371, 1977.

[38] ARÁOZ, R.; MOLGÓ, J.; DE MARSAC, N.T. Neurotoxic cyanobacterial toxins. Toxicon, v. 56(5), p.813-828, 2010.

[39] MELLO, F.D.; BRAIDY, N.; MARÇAL, H.; GUILLEMIN, G.; NABAVI, S. M.; NEILAN, B. A. Mechanisms and effects posed by neurotoxic products of cyanobacteria/microbial eukaryotes/dinoflagellates in algae blooms: A review. Neurotox Res, v. 33(1), p.153-167, 2018.

[40] VAN APELDOORN, M. E.; VAN EGMOND, H. P.; SPEIJERS, G. J.; BAKKER, G. J. Toxins of cyanobacteria. Mol Nutr Food Res, v. 51(1), p.7-60, 2007.

[41] CARMICHAEL, W. W.; GORHAM, P. R. Anatoxins from clones of Anabaena flos-aquae isolated from lakes of western Canada, SIL Communications, 1953-1996, v. 21(1), p. 285$295,1978$.

[42] MAHMOOD, N.A; CARMICHAEL, W.W. The pharmacology of anatoxin-a (s), a neurotoxin produced by the freshwater cyanobacterium Anabaena flos-aquae NRC 525-17. Toxicon, v. 24(5), p.425-434, 1986.

[43] PEARSON, L.; MIHALI, T.; MOFFITT, M.; KELLMANN, R.; NEILAN, B. On the chemistry, toxicology and genetics of the cyanobacterial toxins, microcystin, nodularin, saxitoxin and cylindrospermopsin. Mar drugs, v. 8(5), p.1650-1680, 2010.

[44] SHUMWAY, S.E. Phycotoxin-related shellfish poisoning: Bivalve molluscs are not the only vectors. Rev Fish Sci, v. 3(1), p.1-31, 1995.

[45] TESTAI, E.; SCARDALA, S.; VICHI, S.; BURATTI, F. M.; FUNARI, E. Risk to human health associated with the environmental occurrence of cyanobacterial neurotoxic alkaloids anatoxins and saxitoxins. Crit Rev Toxicol, v. 46(5), p.385-419, 2016.

[46] COX, P. A.; BANACK, S. A.; MURCH, S. J.; RASMUSSEN, U.; TIEN, G.; BIDIGARE, R. R.; METCALF, J. S.; MORRISON, L. F.; CODD, G. A.; BERGMAN, B. Diverse taxa of 
cyanobacteria produce $\beta$-N-methylamino-L-alanine, a neurotoxic amino acid. P Natl Acad Sci, v. 102(14), p.5074-5078, 2005.

[47] COX, P. A.; BANACK, S. A.; MURCH, S. J. Biomagnification of cyanobacterial neurotoxins and neurodegenerative disease among the Chamorro people of Guam. P Natl Acad Sci, 100(23), p.13380-13383, 2003.

[48] CARDEllinA, J. H.; MARNER, F. J.; MOORE, R. E. Seaweed dermatitis: structure of lyngbyatoxin A. Science, v. 204(4389), p.193-195, 1979.

[49] AIMI, N.; ODAKA, H.; SAKAI, S. I.; FUJIKI, H.; SUGANUMA, M.; MOORE, R. E.; PATTERSON, G. M. L. Lyngbyatoxins B and C, two new irritants from Lyngbya majuscula. J Nat Prod, v. 53(6), p.1593-1596, 1990.

[50] WHO, C.T. Microcystin-LR, Guidelines for Drinking Water Quality. World Health Organization, Geneva, p.95-110, 1998.

[51] NHMRC, N., 2011. Australian drinking water guidelines. Commonwealth of Australia.

[52] BRASIL AND MINISTÉRIO DA SAÚDE. PORTARIA NO. 2.914 DE 12 DE DEZEMBRO DE 2011: Dispõe sobre os procedimentos de controle e de vigilância da qualidade da água para consumo humano e seu padrão de potabilidade. Diário Oficial da União, 2011.

[53] $\mathrm{N}^{\mathrm{o}}$, Resolução CONAMA. 357/2005-Dispõe sobre a classificação dos corpos de água e diretrizes ambientais para o seu enquadramento, bem como estabelece as condições e padrões de lançamento de efluentes, e dá outras providências. Data da legislação: 17/03/2005Publicação DOU n ${ }^{\circ}$ 053. de 18/03/2005.

[54] FUNASA. Cianobactérias tóxicas na água para consumo humano na saúde pública e processos de remoção em água para consumo humano. - Brasília: Ministério da Saúde: Fundação Nacional de Saúde, 2003. p.56.

[55] OPPENLÄNDER, T. Photochemical purification of water and air: advanced oxidation processes (AOPs)-principles, reaction mechanisms, reactor concepts. John Wiley \& Sons, 2007.

[56] KNIGHT, J. A. Free radicals: their history and current status in aging and disease. Ann Clin Lab Sci, v. 28(6), p.331-346, 1998. 
[57] PIKAEV, A. K. Current status of the application of ionizing radiation to environmental protection: I. Ionizing radiation sources, natural and drinking water purification (a review). High Energ Chem, v. 34(1), p.1, 2000.

[58] KOVACS, E. AND KERESZTES, A. Effect of gamma and UV-B/C radiation on plant cells. Micron, v. 33(2), p.199-210, 2002.

[59] LIU, S.; ZHAO, Y.; MA, F.; MA, L.; O'SHEA, K.; ZHAO, C.; HU, X.; WU, M. Control of Microcystis aeruginosa growth and associated microcystin cyanotoxin remediation by electron beam irradiation (EBI). RSC Advances, v. 5(40), p. 31292-31297, 2015.

[60] TOMINAGA, F. K.; DOS SANTOS BATISTA, A. P.; TEIXEIRA, A. C. S. C.; BORRELY, S.I. Degradation of diclofenac by electron beam irradiaton: Toxicitiy removal, by-products identification and effect of another pharmaceutical compound. J Env Chem Eng, v. 6(4), p.4605-4611, 2018.

[61] BORRELY, S. I.; SILVA, L. G. A.; DEL SOLE, S. V.; GARCIA, V. S. G.; BOIANI, N. F.; ROSA, J.M. Electron beam irradiation of textile effluents and non-ionic ethoxylated surfactant for toxicity and color removal. Braz J Radiat Sc, 2019.

[62] GARCIA, V. S.; ROSA, J. M.; BORRELY, S.I. Toxicity and color reduction of a textile effluent containing reactive red 239 dye by electron beam irradiation. Radiat Phys Chem, v. 172, p.108765, 2020.

[63] DUARTE, C. L.; SAKAGAMI, M. K.; MAUTONE, C. A.; SAMPA, M. H. DE O.; BORRELY, S. I.; SOMESSARI, E. S. Estudo da radiodegradação dos compostos orgânicos odoríficos Geosmina e Metilisoborniol em água do sistema Guarapiranga. In: INTERNATIONAL NUCLEAR ATLANTIC CONFERENCE. Comissão Nacional de Energia Nuclear, 2008.

[64] ZHANG, J. B.; ZHENG, Z.; YANG, G. J.; ZHAO, Y. F. Degradation of microcystin by gamma irradiation. Nucl Instrum Meth A, v. 580(1), p.687-689, 2007.

[65] SONG, W.; XU, T.; COOPER, W. J.; DIONYSIOU, D. D.; CRUZ, A. A. D. L.; O 'SHEA, K. E. Radiolysis studies on the destruction of microcystin-LR in aqueous solution by hydroxyl radicals. Environ Sci Technol, v. 43(5), p.1487-1492, 2009.

[66] CAVAlCANTE-SILVA, E.; HEREMAN, T. C.; ARTHUR, V.; ANDRETTE, R. DE O.; BITTENCOURT-OLIVEIRA, M. DO C.; ARRUDA-NETO, J. D. DE T. Estudio de la radi- 
osensibilidad a radiación gama de Microcystis panniformis (cianobacteria). Revista Latinoamericana de Biotecnología Ambiental y Algal, v. 1(2), p. 135-142, 2010.

[67] ZHENG, B.; ZHENG, Z.; ZHANG, J.; LUO, X.; LIU, Q.; WANG, J.; ZHAO, Y. The removal of Microcystis aeruginosa in water by gamma-ray irradiation. Sep Purif Technol, v. 85, p. 165-170, 2012.

[68] LIU, S.; ZHAO, Y.; JIANG, W.; WU, M.; MA, F. Inactivation of Microcystis aeruginosa by electron beam irradiation. Water Air Soil Pollut, v. 225(9), p.2093, 2014. 